\title{
PENINGKATAN KETERAMPILAN MENYIMAK MELALUI MODEL PEMBELAJARAN ARTIKULASI DAN MEDIA BONEKA TANGAN PADA PEMBELAJARAN TEMATIK KELAS 1 SDN PEJOK II KEDUNGADEM BOJONEGORO
}

\author{
Ulifatus Pebriana $^{1)}$, Dyah Woro Wirastri Ekowati ${ }^{2}$, Frendy Aru Fantiro ${ }^{3)}$ \\ ${ }^{1)}$ SDN Pejok 2 Bojonegoro, \\ 2,3) PGSD Universitas Muhammadiyah Malang \\ Email: ulifatusfebriana@gmail.com
}

\begin{abstract}
In fact, listening skills of students are still low seen from the completeness of students is only $25 \%$ complete. So, the necessary to attempt improvement through learning model and learning media is used. This study aims to: (1) Describe the application of learning models "Artikulasi dan Media Boneka Tangan" to improve listening skills in thematic learning first grade at SDN Pejok II Kedungadem Bojonegoro, and (2) Explaining the increase in the ability to listen to students after applying the learning model articulation and media dolls hands-on thematic learning first grade at SDN Pejok II Kedungadem Bojonegoro.The results showed (1) the application of learning "Artikulasi dan Media Boneka Tangan" can improve students' listening skills. It can be seen from the percentage of students who complete the first cycle is only $45.8 \%$ of students who completed and then increased to $83.4 \%$ of students who completed the second cycle. (2) Results of votes of teacher activity increased from the first cycle to the second cycle ie from scoring $80.7 \%$ to $86 \%$ and the activity of students in the classical with $80 \%$ to $88 \%$. This suggests that the learning model "Artikulasi dan Media Boneka Tangan" can be used as a reference in the implementation of the learning process that can promote successful learning.
\end{abstract}

Keywords:Improvement, Listening Skills, Learning Model Articulation, Media Dolls Hand.

\begin{abstract}
Abstrak:Pada kenyataannya kemampuan menyimak siswa masih rendah yang terlihat dari nilai ketuntasan siswa yaitu hanya $25 \%$ yang tuntas sehingga perlu adanya upaya peningkatan melalui model pembelajaran dan media pembelajaran yang digunakan. Penelitian ini bertujuan untuk: (1) menjelaskan penerapan model pembelajaran artikulasi dan media boneka tangan untuk meningkatkan kemampuan menyimak pada pembelajaran tematik kelas I dan (2) menjelaskan peningkatan kemampuan menyimak siswa setelah menerapkan model pembelajaran artikulasi dan media boneka tangan pada pembelajaran tematik.Hasil penelitian menunjukkan (1) penerapan model pembelajaran artikulasi dan media boneka tangan dapat meningkatkan keterampilan menyimak siswa. Hal ini dapat dilihat dari presentase siswa yang tuntas yaitu pada siklus I hanya ada 45,8\% siswa yang tuntas dan kemudian meningkat menjadi $83,4 \%$ siswa yang tuntas pada siklus II. (2) Hasil penilaian aktivitas guru meningkat dari siklus I ke siklus II yaitu dari skor $80,7 \%$ menjadi $86 \%$ dan aktivitas siswa secara klasikal dengan skor $80 \%$ menjadi $88 \%$. Hal ini menunjukkan bahwa model pembelajaran artikulasi dan media boneka tangan dapat dijadikan sebagai acuan dalam pelaksanaan proses pembelajaran yang dapat mendukung keberhasilan pembelajaran.
\end{abstract}

Kata Kunci:Peningkatan, Keterampilan Menyimak, Model Pembelajaran Artikulasi,Media Boneka Tangan.

\section{PENDAHULUAN}

Pembelajaran tematik terpadu merupakan pendekatan pembelajaran yang mengintegrasikan berbagai kompetensi dari berbagai mata pelajaran dalam berbagai tema.Pendekatan pembelajaran ini digunakan untuk seluruh kelas pada sekolah dasar. Pembelajaran dengan pendekatan tematik ini mencakup seluruh kompetensi mata pelajaran yaitu: PPKn, Bahasa Indonesia,
IPA, IPS, Matematika, Pendidikan Jasmani Olahraga dan Kesehatan, Seni

Budaya dan Prakarya kecuali mata pelajaran Pendidikan Agama dan Budi Pekerti. Kompetensi mata pelajaran IPA pada kelas I - III diintegrasikan pada mata pelajaran Bahasa Indonesia dan Matematika, sedangkan untuk mata pelajaran IPS diintegrasikan ke mata pelajaran Bahasa Indonesia, PPKN dan Matematika. Kompetensi dasar IPA dan 
IPS di kelas IV-VI masing-masing berdiri sendiri (Kemendikbud: 2014).

Siswa membutuhkan keterampilan komunikasi yang baik untuk memahami konsep-konsep antar bidang studi, baik secara lisan maupun tulisan. Hal ini dapat diajarkan melalui pembelajaran bahasa Indonesia yanghampir ada di setiap pembelajaran, meskipun sudah melebur dengan bidang studi lainnya.Pembelajaran bahasa Indonesia di SD diarahkan untuk meningkatkan kemampuan siswa dalam berkomunikasi dengan baik, baik secara lisan maupun tulisan (Zulela, 2012: 4).

Hasil wawancara dan observasi dengan guru kelas I pada tanggal 30 Agustus 2016 di SDN Pejok II dapat terlihat bahwa permasalahan menyimak masih memerlukan penanganan yang lebih baik lagi. Hal ini dapat dilihat dari nilai siswa pada keterampilan menyimak, dari 24 siswa hanya ada 6 siswa yang mendapatkan nilai diatas KKM, dan selebihnya belum memenuhi KKM. Selain itu, siswa masih suka berbicara sendiri dengan temannya atau melakukan hal lain seperti menggambar, bermainmain sendiri ketika guru menjelaskan atau menyampaikan materi, sehingga berdampak pada pemahaman siswa tentang materi/ konsep yang disampaikan.

Hal ini bisa terjadi karena pada dasarnya karakteristik siswa kelas $1 \mathrm{SD}$ masih terbawa karakteristik pada saat masih TK yaitu suka bermain dan bergembira. Seperti yang terdapat dalam Kemendikbud no 57 Tahun 2014 yang menyebutkan karakteristik siswa SD yaitu senang bergerak, senang bermain, senang melakukan sesuatu secara langsung dan senang bekerja dalam kelompok. Selain itu,siswa menjadi kurang antusias dalam menyimak atau memperhatikan penyampaian materi karena pembelajaran kurang variatif karena pada saat proses pembelajaran guru lebih banyak menggunakan ceramah dan tidak menggunakan media yang dapat mendukung proses pembelajaran.

Sesuai dengan masalah diatas, maka peneliti melakukan variasi model pembelajaran yang dapat membuat siswa fokus untuk menyimak dalam proses pembelajaran yaitu dengan menggunakan model pembelajaran artikulasi yang dipadukan dengan menggunakan media boneka tangan.

\section{Pembelajaran Tematik}

Pembelajaran tematik adalah pembelajaran terpadu yang menggunakan tema untuk mengaitkan beberapa mata pelajaran sehingga dapat memberikanpengalamanbermakna

kepada murid. Kurikulum 2013 SD/ MI menggunakan pendekatan pembelajaran tematik integratif dari kelas I sampai kelas VI. Pembelajaran tematik integratif merupakan pendekatan pembelajaran yang mengintegrasikan berbagai kompetensi dari berbagai mata pelajaran ke dalam berbagai tema. Tema merupakan alat atau wadah untuk mengenal berbagai konsep kepada anak didik secara utuh. Dalam pembelajaran, tema diberikan dengan maksud menyatukan isi kurikulum dalam satu kesatuan yang utuh, , memperkaya perbendaharaan bahasa anak didik dan membuat pembelajaran lebih bermakna.

Adapun karakteristik dari pembelajaran tematik ini menurut TIM Pengembang PGSD, 1997 (Majid, 2014: 90) adalah:

a. Holistik

Suatu gejala atau peristiwa yang menjadi pusat perhatian dalam pembelajaran tematik diamati dan dikaji dan beberapa bidang studi sekaligus, tidak dari sudut pandang yang terkotak-kotak.

b. Bermakna

Pengkajian suatu fenomena dari berbagai macam aspek, memungkinkan terbentuknya semacam jalinan antar-skemata yang dimiliki oleh siswa, yang pada gilirannya akan memberikan dampak kebermaknaan dari materi yang dipelajari.

c. Otentik

Pembelajaran

tematik memungkinkan siswa memahami secara langsung konsep dan prinsip yang ingin dipelajari.

d. Aktif 
Pembelajaran tematik dikembangkan dengan berdasar pada pendekatan inquiry discovery dimana siswa terlibat secara aktif dalam proses pembelajaran, mulai perencanaan, pelaksanaan, hingga proses evaluasi.

\section{Keterampilan Menyimak}

Kurikulum 2013 menguraikan tujuan pembelajaran yang sejalan dengan tujuan pembelajaran bahasa Indonesia, yakni agar siswa terampil berbahasa. Keterampilan berbahasa dibedakan dari empat macam, yaitu menyimak, berbicara, membaca, dan menulis. Keempat keterampilan berbahasa tersebut berkaitan antara satu dan yang lain. Beberapa praktisi masih berpendapat sampai sekarang bahwa pembelajaran bahasa adalah sebuah proses yang berjalan linera/ lurus, yaitu diawali dengan menguasai bahasa lisan (menyimak dan berbicara) dan baru kemudian beralih ke bahasa tulis (membaca dan menulis).

Kegiatan menyimak merupakan kemampuan tahap awal yang harus dikuasai dalam keterampilan berbahasa, dikatakan demikian karena menyimak merupakan suatu cara yang dilakukan untuk memeroleh informasi yang disampaiakn orang lain sehingga dapat diimplementasikan pada tahap berikutnya yaitu berbicara, membaca, dan menuliskannya kembali untuk disampaikan kepada orang lain.Menyimak adalah suatu proses kegiatan mendengarkan lambanglambang lisan dengan penuh perhatian, pemahaman, apresiasi, serta interpretasi untuk memperoleh informasi, menangkap isi atau pesan serta memahami makna komunikasi yang telah disampaikan oleh sang pembicara melalui ujaran atau bahasa lisan (Tarigan, 1994: 28).

\section{Model Pembelajaran Artikulasi}

Model Pembelajaran merupakan suatu kerangka konseptual yang melukiskan prosedur secara sistematis dalam mengorganisasikan pengalaman belalajar untuk mencapai tujuan belajar tertentu dan berfungsi sebagai pedoman bagi para perancang pembelajaran dan para pengajar dalam merencanakan dan melaksanakan aktivitas pembelajaran (Kemendikbud no. 57 tahun 2014). Oleh karena itu beberapa ahli membuat berbagai pengembangan model pembelajaran termasuk model pembelajaran artikulasi.

Model pembelajaran artikulasi adalah pembelajaran dengan sistem pesan berantai (Kurniasih, 2015). Pesan yang akan disampaikan. Pesan yang akan dibawa merupakan materi pelajaran yang sedang dipelajari ketika itu. Secara teknis, setiap siswa wajib meneruskan pesan dan menjelaskannya pada siswa lain (pasangan kelompoknya). Model pembelajaran ini terbilang unik karena siswa akan berperan sebagai "penerima pesan" sekaligus berperan sebagai "penyampai pesan". Model pembelajaran artikulasi ini baik digunakan dalam rangka meningkatkan daya ingat dan daya serap siswa dalam memahami materi yang diajarkan kepadanya (Widhiastanto, 2016: 114).

Model pembelajaran artikulasi ini memiliki beberapa kelebihan (Kurniasih, 2015) yaitu a)Semua siswa terlibat (mendapat peran), b)Melatih kesiapan siswa, c) Melatih daya serap pemahaman dari orang lain, d) Cocok untuk tugas sederhana, e) Interaksi lebih mudah, f) Lebih mudah dan cepat membentuknya dan g) Meningkatkan partisipasi anak.

Selain kelebihan, model pembelajaran artikulasi juga memeiliki beberapa kelemahan sebagai berikut: a)Jika ada satu siswa yang tidak mengerti atau tidak paham materi pelajaran, maka siswa yang lainpun akan mendapatkan informasi yang sama, b) Rentan akan kegaduhan jika guru secara teknik kurang bisa menguasai kelas, c) Waktu yang dibutuhkan banyak agar materi tersampaikan semuanya, d) Banyak kelompok yang melapor dan perlu dimonitor dan e) Jika ada perselisihan tidak ada penengah. Oleh karena itu, peneliti mengkolaborasikan dengan media boneka tangan untuk menutupi kekurangan dari model pembelajaran yang digunakan.

Adapun langkah-langkah model pembelajaran artikulasi adalah: 
a. Pertama kali guru menerangkan pelajaran apa yang hendak dibahas serta menjelaskan model pembelajaran yang hendak digunakan

b. Guru menyampaikan kompetensi yang ingin dicapai

c. Guru menyajikan materi sebagaimana biasanya hingga siswa paham

d. Untuk mengetahui daya serap siswa, bentuklah kelompok berpasangan

e. Menugaskan salah satu siswa dari pasangan itu menceritakan materi yang baru diterima dari guru dan pasangannya mendengar sambil membuat catatan-catatan kecil, kemudian berganti peran, begitu juga kelompok lainnya.

f. Menugaskan siswa secara bergiliran atau bisa juga dengan cara diundi atau diacak menyampaikan hasil wawancara dengan teman pasangannya sampai sebagian siswa sudah mnyampaikan hasil wawancaranya

g. Guru mengulang kembali materi yang sekiranya belum dipahami

h. Kemudian menyimpulkan materi dan menutup pembelajaran.

\section{Media Boneka Tangan}

Media pembelajaran bisa dikatakan sebagai alat yang bisa merangsang siswa shingga terjadi proses belajar.Media Pembelajaran segala sesuatu yang dapat digunakan untuk menyalurkan pesan dari pengirim ke penerima sehingga dapat merangsang pikiran, perasaan, perhatian, dan minat serta perhatian siswa sedemikian rupa sehingga proses belajar terjadi (Sadiman, 2006: 7)

Berdasarkan pengertian media di atas, media boneka tangan merupakan alat peraga yang dapat membantu dalam penyampaian materi dalam proses pembelajaran. Menurut Daryanto (2011: 31) dalam Annisa (2015: 1705), boneka tangan adalah benda tiruan dari bentuk manusia, binatang, atau tumbuhan yang dimainkan dengan satu tangan. Boneka tangan dapat dijadikan media pendidikan, boneka dapat dimainkan dalam bentuk sandiwara boneka. Boneka tangan adalah boneka yang digerakkan dari bawah oleh seseorang yang tangannya di masukkan ke bawah pakaian boneka. Disebut boneka tangan karena yang menggerakkan adalah tangan manusia.

Dalam penggunaan media boneka tangn perlu memperhatikan beberapa hal, sehingga peneliti membuat langkahlangkah penggunaan media boneka tangan dalam proses pembelajaran sebagai berikut:

a. Menyiapkan boneka tangan yang sesuai dengan tema yaitu boneka berbentuk hewan dan tumbuhan.

b. Menggunakan media boneka tangan untuk menjelaskan materi pelajaran dengan cara sebgai berikut:

1) Memasukkan tangan pada boneka tangan dalam memainkannya

2) Menjelaskan materi menggunakan boneka, misalnya tentang benda hidup berarti menjelaskan menggunakan hewan dan tumbuhan.

c. Merapikan kembali boneka yang selesai digunakan.

\section{METODE}

Jenis penelitian yang digunakan adalah Penelitian Tindakan Kelas (PTK) model Hopkins dengan pendekatan kualitatif. Pelaksanaan penelitan tindakan dilakukan membentuk spiral yang dimulai dari merasakan adanya masalah, menyusun perencanaan, melaksanakan tindakan, melakukan observasi, mengadakan refleksi, melakukan rencana ulang, melaksanakan tindakan, dan seterusnya (Sanjaya, 2013: 53).

Dalam pelaksanaannya peneliti berkolaborasi dengan guru kelas I di SDN Pejok II pada saat proses pembelajaran, selain itu guru juga membantu dalam mengobservasi atau melakukan pengamatan terhadap peneliti pada saat melaksanakan tindakan (mengajar) serta sebagai teman diskusi dalamproses pembelajaran dan juga refleksi terhadap proses pembelajaran yang telahberlangsung untuk merencanakan tindakan perbaikan indikator yang belum tercapai.Subyek dari penelitian ini adalah siswa kelas I dengan jumlah siswa 24 orang yang 
terdiri atas 13 siswa laki-laki dan 11 siswa perempuan.

Teknik pengumpulan data dalam penelitian ini menggunakan wawancara, angket, catatan lapang, serta memberikan tes unjuk kerja pada siswa. Dan sumber data dari penelitian ini adalah guru dan siswa, sedangkan peneliti sebagai pengumpul data, pengolah data, serta pelapor data.

\section{Hasil dan Pembahasan}

Hasil penelitian yang telah dilakukan oleh peneliti dapat dikatakan berhasil. Hal ini dapat terlihat dari nilai ketuntasan siswa yang mencapai 83,4 \% pada siklus II. Nilai ketuntasan ini didapatkan dari nilai tes unjuk kerja keterampilan menyimak berupa menceritakan kembali isi teks deskriptif pada lembar kerja yang telah disiapkan.

Tabel 1Penilaian Keterampilan Menyimak Siklus II

\begin{tabular}{|c|c|c|c|c|c|}
\hline $\begin{array}{l}\mathrm{N} \\
\text { o. }\end{array}$ & $\begin{array}{c}\text { Nil } \\
\text { ai }\end{array}$ & $\begin{array}{c}\text { Kualifi } \\
\text { kasi }\end{array}$ & $\begin{array}{c}\text { Frekue } \\
\text { nsi }\end{array}$ & $\begin{array}{c}\text { Persent } \\
\text { ase }\end{array}$ & $\begin{array}{c}\text { Keteran } \\
\text { gan }\end{array}$ \\
\hline 1. & $\begin{array}{c}86- \\
10 \\
0\end{array}$ & $\begin{array}{c}\text { Sangat } \\
\text { Baik }\end{array}$ & 13 & 54.2 & $\begin{array}{l}\text { Dari } 24 \\
\text { siswa, } \\
13\end{array}$ \\
\hline 2. & $\begin{array}{l}70- \\
85\end{array}$ & Baik & 7 & 29,2 & $\begin{array}{l}\text { siswa } \\
\text { terdapat }\end{array}$ \\
\hline 3. & $\begin{array}{l}55- \\
69 \\
\end{array}$ & Cukup & 4 & 16,6 & $\begin{array}{l}\text { pada } \\
\text { kualifik }\end{array}$ \\
\hline 4. & $\begin{array}{l}40- \\
54 \\
\end{array}$ & Kurang & 0 & 0 & $\begin{array}{l}\text { asi } \\
\text { sangat }\end{array}$ \\
\hline 5. & $\begin{array}{l}0- \\
39 \\
\end{array}$ & $\begin{array}{l}\text { Sangat } \\
\text { Kurang }\end{array}$ & 0 & 0 & $\begin{array}{l}\text { baik, } 7 \\
\text { siswa }\end{array}$ \\
\hline \multicolumn{3}{|c|}{ Jumlah } & 24 & 100 & $\begin{array}{l}\text { dan } 4 \\
\text { siswa } \\
\text { cukup. }\end{array}$ \\
\hline
\end{tabular}

Selain melihat dari nilai ketuntasan siswa, aktivitas siswa dan aktivitas guru pada proses pembelajaran juga harus baik. Oleh karena itu peneliti membuat lembar observasi guru dan siswa untuk menilai aktivitas guru dan siswa. Dapat dilihat pada tabel dibawah ini.

Tabel 2 Aktivitas guru siklus II

\begin{tabular}{clcc}
\hline No & Kompetensi & $\begin{array}{c}\text { Banyaknya } \\
\text { Indikator }\end{array}$ & $\begin{array}{c}\text { Skor } \\
\text { yang } \\
\text { diperoleh }\end{array}$ \\
\hline 1. & $\begin{array}{l}\text { Kegiatan } \\
\text { Awal }\end{array}$ & 4 & 10 \\
\hline 2. & $\begin{array}{l}\text { Kegiatan } \\
\text { Inti }\end{array}$ & 12 & 31 \\
\hline
\end{tabular}

\begin{tabular}{cccc}
\hline 3. $\begin{array}{l}\text { Kegiatan } \\
\text { Akhir }\end{array}$ & 3 & 8 & \\
\hline Total & 19 & 49 & \\
\hline $\begin{array}{c}\text { Jumlah skor yang } \\
\text { muncul }\end{array}$ & & & 49 \\
\hline Presentase & & & 86 \\
& & & $\%$ \\
\hline
\end{tabular}

Tabel 3 Aktivitas siswa siklus II

\begin{tabular}{|c|c|c|c|c|}
\hline No & Kompetensi & $\begin{array}{l}\text { Banyaknya } \\
\text { Indikator }\end{array}$ & $\begin{array}{c}\text { Skor } \\
\text { yang } \\
\text { diperoleh }\end{array}$ & \\
\hline 1. & $\begin{array}{l}\text { Kegiatan } \\
\text { Awal }\end{array}$ & 4 & 17 & \\
\hline 2. & $\begin{array}{l}\text { Kegiatan } \\
\text { Inti }\end{array}$ & 9 & 40 & \\
\hline 3. & $\begin{array}{l}\text { Kegiatan } \\
\text { Akhir }\end{array}$ & 2 & 9 & \\
\hline & Total & 15 & 66 & \\
\hline \multicolumn{2}{|c|}{$\begin{array}{c}\text { Jumlah skor yang } \\
\text { muncul }\end{array}$} & & & 66 \\
\hline & resentase & & & $\begin{array}{l}88 \\
\%\end{array}$ \\
\hline
\end{tabular}

Secara keseluruhan dapat dikatakan bahwa, pelaksanaan pembelajaran dengan menggunakan model pembelajaran artikulasi dan media boneka tangan telah berhasil dilaksanakan. Keberhasilan ini ditunjukkan dengan adanya peningkatan pelaksanaan pembelajaran yaitu pada siklus I persentase aktivitas guru dalam melaksanakan pembelajaran mendapat skor $80,7 \%$ atau dalam kualifikasi "Baik"dan pada siklus II, persentase keterlaksanaan pembelajaranmendapat skor $86 \%$ atau dalam kualifikasi "Sangat Baik". Selain dilihat dari aktivitas guru, keberhasilan pembelajaran juga dilihat dari aktivitas siswa yang menunjukkan adanya peningkatan dari siklus I ke siklus II. Presentase aktivitas siswa pada siklus I adalah $80 \%$ atau dalam kualifikasi "Baik" dan mengalami peningkatan pada siklus II menjadi $88 \%$ atau dalam kualifikasi "Sangat Baik". Selain itu, respon positif dari siswa dan guru kelas juga menunjukkan keberhasilan penerapan model pembelajaran artikulasi dan media boneka tangan yang dapat dilihat dari hasil wawancara dengan guru kelas dan beberapa sampel siswa.

\section{Kesimpulan dan Saran}

Dari hasil pembahasan dapat disimpulkan bahwa penerapan model pembelajaran artikulasi dan media 
boneka tangan dapat meningkatkan keterampilan menyimak siswa kelas 1 SDN Pejok II. Haltersebut terlihat dari penilaian keterampilan menyimak dan terjadipeningkatan siswa yang tuntas dari siklus I dan siklus II. Pada siklus I ada 11 siswa $(45,8 \%)$ yang tuntas dan pada siklus II meningkat menjadi 20 siswa $(83,4 \%)$ yang tuntas.

Tetapi dalam pelaksanaan penelitian terdapat beberapa kekurangan yang dilakukan peneliti. Sehingga peneliti memberikan beberapa saran untuk penelitian selanjutnya sebagai berikut:

1. Peneliti selanjutnya

a. Mempersiapkan dengan lebih matang lagi ketika akan mengajar, baik dari langkahlangkah kegiatan dalam pembelajaran maupun media yang akan digunakan.

b. Dalam proses pembelajaran, peneliti (bertindak sebagai guru) harus lebih menguasai kelas agar semua siswa dapat aktif dalam proses pembelajaran dengan cara memberikan pertanyaan kepada siswa yang ramai.

c. Lebih menyempurnakan langkah-langkah penerapan model pembelajaran artikulasi dan media boneka tangan dengan cara memadukan dengan lebih inovasi lagi agar dapat tercipta pembelajaran yang lebih inovatif lagi.

2. Guru

a. Guru selalu melakukan variasi proses belajar mengajar, terutama menggunakan model dan metode pembelajaran yang dapat membuat siswa aktif dalam proses pembelajaran.

b. Guru dapat melakukan beberapa hal untuk siswa yang belum tuntas dan siswa yang kurang atif dalam proses pembelajaran sebagai berikut:

1) Lebih memperhatikan siswa tersebut, misalnya dengan sering melihat pekerjaan siswa ketika dikelas dan menjelaskan kembali secara personal kepada siswa tersebut.

2) Sebaiknya guru me-rolling posisi duduk siswa, agar semua siswa dapat merasakan posisi duduk di depan.

3) Dalam pembagian kelompok, anggota kelompok harus heterogen yaitu terdiri dari siswa yang memiliki kemampuan tinggi dan siswa yang memiliki kemampuan kurang.

\section{Daftar Pustaka}

Afandi, R. 2015. Pengembangan Media Permaianan Ular Tangga Untuk Meningkatkan Motivasi Belajar Siswa dan Hasil Belajar IPS di Sekolah Dasar. JINoP(Jurnal Inovasi Pemblajaran). 1(1): 77-89.

Ahmad, Nur Aina. Februari 2015. Penerapan Teknik Menulis Cepat (Speedwriting) Dalam Pembelajaran Menulis Deskriptif. Jurnal Managemen Pendidikan Islam. Vol $3: 88$ - 96.

Anggraeni, Desi. 2015. Peningkatan Keterampilan Menyimak Penjelasan Denah Melalui Penbelajaran Tipe STAD (Students Teams Achievement Divisions) Pada Kelas IV MI Terpadu Salsabila, Kalisari, Pasar Rebo, Jakarta Timur. Skripsi tidak diterbitkan. Jakarta: PGMI FITK UIN Syarif Hidayatullah.

Arifin, Zaenal. 2010. Evaluasi Pembelajaran. Bandung: Remaja Rosdakarya.

Fakhriyah, Fina, dkk. Desember 2014. Penerapan Pembelajaran Tematik Berwawasan Multiple Intellegence Dalam Upaya Membentuk Karakter Siswa di SD IT Al Islam Kudus. Jurnal Refleksi Edukatika. Vol $5: 44-50$. 
Ghazali, A. Syukur. 2013. Pembelajaran Keterampilan Berbahasa Dengan Pendekatan Komunikatif-Interaktif. Malang: PT Refika Aditama.

Haryono, Ari Dwi. 2014. Metode Praktis Pengembangan Sumber dan Media Pembelajaran. Malang: GENIUS MEDIA.

Kemendikbud. 2014. Permendikbud No. 57 tentang Kurikulum 203 SD/ MI. Jakarta : Kementrian Pendidikan dan Kebudayaan.

Kurniasih, Imas \& Berlin Sani. 2015. Ragam Pengembangan Model Pembelajaran Untuk Peningkatan Profesionalitas Guru. Yogyakarta: Kata Pena.

Majid, Abdul. 2014. Pembelajaran Tematik Terpadu. Bandung: PT REMAJA ROSDAKARYA.

Mulyasari, Ultria. 2015. Penggunaan Media Boneka Tangan Untuk Meningkatkan Kemamapuan Menyimak Cerita Pada Siswa Kelas 1 SDN Madyopuro 03 Kota Malang. Skripsi tidak diterbitkan. Malang: PGSD FIP UM.

Permana, Erwin Putera. Desember 2015. Pengembangan Media Pembelajaran Boneka Kaus Kaki Untuk Meningkatkan Keterampilan Berbicara Siswa Kelas II Sekolah Dasar. Jurnal Pendidikan Dasar. Vol $2: 133-140$

Putri, Silviana Yustika Permata. 2015. Penggunaan Model Pembelajaran Artikulasi Untuk Meningkatkan Keterampilan Menyimak. Skripsi tidak diterbitkan. Surakarta: PGSD FKIP Universitas Sebelas MaretSadiman, Arief S., dkk. 2006. Media Pendidikan Pengertian, Pengembangan, dan Pemanfaatannya. Jakarta: PT Raja Grafoindo Persada.

Safitri, Annisa Rahmi. 2015. Pengaruh Penggunaan Media Boneka Tangan Terhadap Keterampilan Bercerita

\section{Siswa Kelas II SDN KERET KREMBUNG SIDOARJO. JPGSD. Vol $03: 1-10$.}

Sanjaya, Wina,. 2013. Penelitian Tindakan Kelas. Jakarta: KENCANA Prenada Media Group.

Sugiyono. 2015. Metode Penelitian Kuantitatif Kualitatif dan R\&D. Bandung:ALFABETA

Susanto, Heru dan Eti Sunarsih. 2015. Model Pembelajaran Cooperative Tipe Script Sebagai Upaya Meningkatkan Keterampilan Menyimak Dongeng Siswa SMP. Seminar Nasional Pendidikan Bahasa Indonesia. ISSN: 2477636X (273 - 279).

Tarigan, Henry Guntur,. 1994. Menyimak Sebagai Suatu Keterampilan Berbahasa. Bandung: Angkasa.

Utomo, Dwi Priyo dan Ida Arijanny. 2009. MATEMATIKA Untuk Kelas 1 SD/MI BSE. Jakarta: Pusat Perbukuan Depdiknas.

Widhiastanto, Yohanes. Juni 2016. Studi Komparasi Tentang Prestasi Belajar Antara Menggunakan MetodeArtikulasi Dengan Metode Cooperative Script Bidang Studi PendidikanKewarganegaraan Pada Siswa Kelas X SMK PGRI 4 NgawiTahun Pelajaran 2014/2015". Jurnal Media Prestasi . Vol XVII :104 - 120 .

Yousika, Irine. 2012. Pengaruh Penggunaan Media Boneka Tangan Terhadap Hasil Belajar Keterampilan Menyimak Dongeng Siswa Kelas II SDN Tanjungrejo 5 Kota Malang. Skripsi tidak diterbitkan. Malang: PGSD KSDP FIP UM.

Zulela. 2012. Pembelajaran Bahasa Indonesia Apresiasi Sastra di Sekolah Dasar. Bandung: PT REMAJA ROSDAKARYA. 